\title{
Impact of Globalization on Human Development: A Panel Data Analysis of Selected South Asian Countries
}

\author{
Amber Hasan ", Abdul Waheed \\ Department of Economics, Faculty of Arts and Social Sciences, University of Karachi, Pakistan \\ E-mail: amberzaman235@gmail.com
}

Received: 4 September 2020; Revised: 20 October 2020; Accepted: 28 October 2020

\begin{abstract}
This study tends to evaluate the impact of globalization on human development in developing countries. The objective has been achieved by analyzing the data of six SAARC countries (Pakistan, India, Sri-Lanka, Bhutan, Bangladesh, and Nepal) over 20 years from 2000-2019. Afghanistan and Maldives were removed from the study because of the unavailability of data. The multiple regression model is used for estimation, which includes many economic and demographic variables. The focused independent variables are the trade openness and foreign direct investment (FDI), which are used as a proxy for globalization. Other explanatory variables are GDP growth, percentage of the population using safely managed sanitation services, infant mortality ratio, maternal mortality ratio, birth rate, death rate, and dependency ratio ( $\%$ of working-age population). Hausman test has indicated that the fixed effect model is appropriate for this study. The results of fixed effect estimation indicated that FDI has positive while trade openness has a negative impact on Human Development in selected South Asian countries.
\end{abstract}

Keywords: human development, globalization, trade openness

\section{Introduction}

As per definition, globalization is the increasing integration of economies around the world through goods, services, financial flows, and the movement of ideas and people. Besides many benefits, the accelerated pace of globalization has proven to be destructive as well. According to World bank report, between 1960 to 1980, the world's per capita income increased by $83 \%$, while in the globalization era from 1980 till present, it fell to $33 \%$. These figures mark question on the studies that favor the beneficial impact of globalization. Various literature supports the existence of a positive relationship between globalization (trade openness) and human development, as globalization and economic integrations have the potential to generate employment, market expansion, better use of resources, the spread of technological knowledge. However, globalization does not confirm human development, as globalization's impact is highly dependent on the country's social and institutional conditions. This effect has been widely studied in (Dash et al., 2018; Figueroa, 2014; Sabi, 2007; Salvatore \& Wiley, 2004).

Developing countries (especially Pakistan, India, Nepal, Bangladesh, Bhutan, and Sri-Lanka) mostly export primary goods that have low prices and import finished goods that have higher prices. Hence, their import bill exceeds their export bill, and they have to suffer a trade deficit. This negative influence of trade openness prove the adverse

Copyright (C2020 Amber Hasan, et al

DOI: https://doi.org/10.37256/ges.212021629

This is an open-access article distributed under a CC BY license

(Creative Commons Attribution 4.0 International License)

https://creativecommons.org/licenses/by/4.0/ 
effect of globalization. However, FDI supports economic growth and thus has a positive effect on Human Development Index (HDI). In the year 2019's HDI ranking, Sri-Lanka ranked (71), India (129), Bhutan (134), Bangladesh (135), Nepal (147), while Pakistan stood with rank (152), out of 189 countries.

South Asian region constitute about 23 percent of the world's population and has potential to increase growth by trade expansion among its countries but facing challenges (Babar \& Khandare, 2012). In the earlier period of the era of globalization, many developing countries have adopted trade liberalization reforms involving the reduction of import and export tariffs and non-tariff barriers. However, that increase in trade openness proved to be detrimental to economic growth by increasing inflation and lowering exchange rates (Keho, 2017). A number of studies support the idea of positive growth effects of trade openness (Chang et al., 2009; Frankel \& Romer, 1999; Freund \& Bolaky, 2008). Other studies oppose the existence of a positive link between trade and economic growth (Musila \& Yiheyis, 2015; Polat et al., 2015; Ulasan, 2015). Most of the studies presented above, were failed in explaining the reason behind the positive or negative influence of global trade openness and economic growth. The element of resolving the issue is also missing. Therefore, this gap in the existing literature needs to be filled. The requisite compelled to present a comprehensive study that not only analyze the impact of globalization or trade openness by taking all the factors in consideration that were missing in earlier literature but also figure out the causes and present a practical approach to eliminate the issues.

This research has been done to find whether globalization is beneficial for developing countries or harmful. It has been found that almost all previous studies used the living standard indicators to study the impact of globalization on human development. Also, the influence of globalization has been analyzed in general. The contribution of this research is analyzing the impact of globalization on a dis-aggregated level using both trade and human development indicators. To achieve this objective panel data of six South Asian countries, who are associated in trade block SAARC, has been analyzed. The research proceeded employing fixed effect regression estimation. The findings of the research would benefit the developing countries specially those under study to device the policies particularly the trade policies accordingly. For instance, the countries having a negative trade and development nexus should not only increase their production in order to reduce import, but they must also identify the other factors which are causing hindrance in getting the benefits of trade like developed countries. While, those countries where globalization is supporting human development should analyze its unprecedented feature and work in direction to improve it further.

The research question is that, whether globalization has a positive or negative impact on HDI of developing countries. The research also tends to answer that whether countries internal features influence the HDI and globalization nexus and also identify the factors that strengthens the impact of globalization in developing countries.

This brief introduction is followed by a review of theoretical literature and a review of empirical literature in Section 2 and Section 3, respectively. The empirical framework is discussed in section 4. Preliminary data analysis and estimation results are presented in section 5. Section 6 concludes the study with policy implications and set directions for further research.

\section{Review of theoretical literature}

The HDI, as presented in the Asia Pacific Human Development Report (UNDP, 2019), is the measure of human development that focuses on three key dimensions, i.e., a long and healthy life, education, and standard of living. The health dimension is calculated by life expectancy at birth. The education dimension is measured by average years of schooling. Whereas, GNI per capita measures the standard of living.

The neo-classical welfare gain analysis describes that, through the exploitation of comparative advantage, a reduction in trade barriers increases trade and productivity, increases GDP through capital accumulation and reallocation of resources, but the higher growth lasts only for the transitional period. Theories that were relevant to trade openness are usually based on models of technological change. Trade can accelerate the rate of technological progress, hence productivity growth, either through an expansion of the input's markets or output's markets.

Globalization supports economic growth, but it is not necessarily sufficient for human development. As mentioned above, human development is highly dependent on other factors as well. Some countries face surplus labor issues when it increases the import of technology or machinery that reduces the need for labor for producing goods. In contrast, the movement of skilled labor from developing countries to developed countries causes brain drain in developing countries. 
At the same time, these comparatively cheap labor movements result in job losses of the nationals in the host country.

Salvatore and Wiley (2004) remarked that the benefits of trade differ depending on the nature of the country. In small countries, the changes in the domestic market do not influence the international price. Thus, the trade barrier causes welfare loss in small developing countries. Whereas, changes in the domestic market of large countries causes a change in international price. Therefore, positive welfare gains are possible from the imposition of trade barriers in large countries.

The unproductive government expenditure, such as defense expenditure, indicates diversion of resources from productive activities to non-productive, such as the purchase of weapons and recruitment of productive members of society for military services. This diversion is likely to reduce general welfare, as resources available for other productive and welfare-enhancing activities will be less. As Blanton (1999) stated, “...the acquisition of arms may tempt the military to forcefully require and maintain acquiescence to the state, even at the expense of individual liberties". Thus, a negative relationship between defense expenditure as a percentage of gross national product and the human development index is predicted.

\section{Review of empirical literature}

In this section, some empirical studies on the relationship between globalization and human development have been presented. Since this study is using panel data for investigation; therefore, the reviewed literature mostly focuses on discussing the findings of studies that used panel data.

Olagunju et al. (2019) applying the System Generalized Method of Movement (SGMM) over the cross-country panel data of 110 developing countries from 1970 to 2015, analyzed the impact of globalization and human capital on the welfare of developing countries. The model used poverty as a dependent variable, whereas globalization and human capital were used as independent variables. The empirical result indicated that globalization reduces the poverty gap and the child mortality rate. Another indication suggests that education and the health dimensions of human capital strengthen the impact of aggregate globalization.

Dash et al. (2018) analyzed the diverse impact of globalization on human development indicators of different countries, using the pre-globalization and post-globalization period data of India, Japan, and Singapore. The period from 1969-1991 has been taken for pre-globalization analysis whereas, 1991-2014 is the period for post-globalization analysis. The comparison of findings of multiple regression analysis of each country confirmed that the impact of globalization differs significantly from country to country, depending on their economies' features.

Waheed and Tehseen (2017) investigated the effect of aggregate and disaggregate trade on Pakistan's human development, using time series data from 1980-2013. They constructed five models of human development with total trade, aggregate exports, aggregate imports, the export of primary, semi-manufactured, and manufactured goods and imports of industrial raw materials, consumer, and capital goods. They concluded that trade has a positive impact on human development in Pakistan.

Figueroa (2004) explained that globalization's diverse impact on human development depends upon their measurement, level of fragility, and delinquency. Data of 17 Latin American countries over the period of 1995 to 2009 has been used for analysis. The study presented three different dimensions of globalization, i.e., Economic, Social, and Political. The empirical result concluded that economic globalization adversely affects GDP per capita, life expectancy, and public investment in education in developing countries. Whereas, the effect of social globalization is otherwise. However, political globalization positively affects the GDP per capita and life expectancy, but its effect is negative on public investment in education.

Sapkota (2011) drawing attention towards the KOF Index of Globalization (which promotes human and gender development and reduces human poverty), used annual panel data of 124 developing countries from 1997 to 2006 to analyze the impact of globalization on different human aspects of development. The Generalized Least Squares (GLS) random effect estimation model's findings indicated that all three aspects of globalization, i.e., economic, social, and political, go along together to contribute the overall effect of globalization rather than contradict each other.

Sabi (2007) considering economic liberalization as a measure of the social impact of globalization applied regression analysis on a cross-section of about 150 countries, concluded that, in developing countries with low or 
middle income, globalization is not related to human development ranking. Globalization exerts influence on human development only after a certain level of income. The result also confirms that globalization intensifies income inequality.

Dowrick and Golley (2004) investigated the dynamic impact of trade openness by comparing different periods of data from 1960-1970, 1970-1980, 1980-1990 of various countries. A structural model consisting of three equations, i.e., growth equation, investment equation, and openness equation, has been designed to measure the impact of policy measure on openness, the effect of openness on productivity, and investment. Results confirmed that trade openness promoted convergence in the 1960s and 1970s. However, since 1980, trade accrued benefits mostly went to the more prosperous economies, with little benefits to the less developed economies. The author explained that the difference in the impact between rich and poor economies is due to inappropriate internal policies and institutions.

Yanikkaya (2002) using two groups of trade openness measures, applied cross-country regression to a panel of over 100 developed and developing countries over the period from 1970 to 1997. The first group used various measures of trade volumes. Trade shares are found to be significantly and positively correlated with growth. In the second group, new measures of trade intensities were introduced, which are trade with OECD countries, non-OECD countries, and U.S. bilateral trade figures. Significant positive coefficients for these measures show that trade barriers are positively and, in most specifications, significantly associated with growth, especially for the developing countries.

Eufuszari (1996) examined the correlation coefficients between Dollar's openness index and set of 11 measures of human development, including the level and rate of change of the Human Development Index (HDI) between 19701985. The income distribution adjusted HDI, the level and rate of change of the under-five mortality rate, and the proportion of the population with access to safe water were used. The results mentioned that economies that are more open to international trade have a higher level of HDI, lower under-five mortality rates, and a higher proportion of the population with access to safe water.

The studies discussed above presented mixed results. Some investigations evaluated a positive impact of globalization on human development (Eusufzai, 1996; Figueroa, 2014; Jawaid \& Waheed, 2017; Olagunju et al., 2019; Yanikkaya, 2002) while other studies observed a negative relationship between globalization and human development (Dowrick \& Golley, 2004; Sabi, 2007; Salvatore \& Wiley, 2004). This study attempts to identify whether the discussed relationship has any positive or negative significance for developing countries.

\section{Empirical framework}

From the review of the earlier theoretical and empirical literature, it has been observed that almost all previous studies used either trade indicators or living standard indicators to study the impact of globalization on human development. Many pieces of research have been done to identify the influence of globalization in general, very few works are done to analyze its impact on dis-aggregated level. The contribution of this research is analyzing the impact of globalization on a dis-aggregated level using both trade and human development indicators.

The study used nine core macro-economic variables to analyze the impact of increasing globalization and trade liberalization on developing economies' human development. The six countries under study are Pakistan, India, SriLanka, Bhutan, Bangladesh, and Nepal. Data is analyzed for a period of 20 years from 2000-2019. Openness is expected to be negatively linked with HDI, as the study is for developing countries, whereas, the expected sign of FDI is positive as developing countries are overly dependent on foreign investment not only for production growth but also for development expenditures. Not only the birth rate but also the sign of death rate is expected to be positive because the increased death rate reduces excess population burden from the economy. GDP growth and access to sanitation facilities are expected to positively influence human development, unlike maternal and infant mortality rates, which are expected to negatively link with HDI. The increased ratio of the dependent population is also assumed to affect human development negatively. 


$$
\begin{aligned}
& \mathrm{HDI}_{\mathrm{it}}=\beta_{0}+\beta_{1} \mathrm{OPEN}_{\mathrm{it}}+\beta_{2} \mathrm{FDI}_{\mathrm{it}}+\beta_{3} \mathrm{BR}_{\mathrm{it}}+\beta_{4} \mathrm{DR}_{\mathrm{it}}+\beta_{5} \mathrm{GDPGR}_{\mathrm{it}} \\
& \quad+\beta_{6} \mathrm{MMR}_{\mathrm{it}}+\beta_{7} \mathrm{DEPEND}_{\mathrm{it}}+\beta_{8} \mathrm{INFAM}_{\mathrm{it}}+\beta_{9} \mathrm{SANAT}_{\mathrm{it}}+\mu_{\mathrm{it}}
\end{aligned}
$$

where, HDI is Human development index, OPEN is the sum of total imports and total exports as a percentage of GDP. FDI is foreign direct investment, BR is a crude birth rate per 1000 live births, DR is death rate, GDPGR is GDP growth annual, MMR is maternal mortality ratio, DEPEND is dependent population ratio to the percentage of the workingage population, INFAM is Infant mortality rate per 1000 live births, SANAT is the percentage of the population access to necessary sanitation facilities. $\beta_{0}$ is a constant term, $\beta_{1}-\beta_{9}$ are parameters which need to be estimated. Except GDP growth, FDI, and Access to Sanitation facilities, all the variables were taken in log form to linearize the series.

The data of six SAARC countries (Pakistan, India, Sri-Lanka, Bhutan, Bangladesh, and Nepal) over the period of 20 years from 2000-2019 has been taken from World Development Indicator (WDI) data bank and UNDP official websites. Afghanistan and Maldives were removed from the study because of the unavailability of information. The focus variables Trade openness (Sum of import and export as a percentage of GDP) and foreign direct investment are used as a proxy for globalization. At the same time, the dependent variable, the Human Development Index (HDI) is used as a measure of human development.

\section{Preliminary analysis and estimation results}

\subsection{Preliminary data analysis}

The data of each country i.e., Bangladesh, Bhutan, Nepal, India, Sri-Lanka, and Pakistan, has been evaluated and reported in Table 1 to 6 . Tables 1, 3, 4, and 5 are indicating that the data of all variables of Bangladesh, Nepal, India, and Sri-Lanka are normally distributed. Whereas, in Table 2, Bhutan's descriptive statistics show that FDI and GDP growth are not distributed normally. It has been observed that the data of FDI in Pakistan is not normally distributed.

Table 1. Descriptive statistics of Bangladesh

\begin{tabular}{ccccccccccc}
\hline & HDI & OPEN & FDI & DR & BR & MMR & INFAM & SANAT & GDPGR & DEPEND \\
\hline Mean & 0.542 & 37.871 & 0.937 & 5.940 & 21.971 & 283.830 & 41.575 & 37.978 & 6.096 & 58.603 \\
Median & 0.542 & 38.178 & 1.018 & 5.770 & 21.356 & 263.500 & 39.950 & 38.532 & 6.262 & 58.645 \\
Max & 0.614 & 48.110 & 1.735 & 6.883 & 27.493 & 434.000 & 63.900 & 48.233 & 7.863 & 68.950 \\
Mini & 0.470 & 26.858 & 0.095 & 5.529 & 18.184 & 173.000 & 25.100 & 25.644 & 3.833 & 48.952 \\
Std. Dev. & 0.046 & 6.464 & 0.436 & 0.440 & 2.975 & 85.495 & 12.276 & 7.287 & 1.002 & 6.247 \\
Skew & 0.017 & -0.187 & -0.238 & 0.810 & 0.443 & 0.476 & 0.328 & -0.206 & -0.391 & 0.071 \\
Kurtosis & 1.693 & 2.084 & 2.484 & 2.331 & 1.899 & 1.875 & 1.842 & 1.712 & 2.604 & 1.782 \\
J-Bera & 1.422 & 0.816 & 0.410 & 2.562 & 1.664 & 1.810 & 1.476 & 1.524 & 0.639 & 1.252 \\
Prob & 0.490 & 0.664 & 0.814 & 0.277 & 0.435 & 0.404 & 0.477 & 0.466 & 0.726 & 0.534 \\
\hline
\end{tabular}

Source: Authors' estimation 
Table 2. Descriptive statistics of Bhutan

\begin{tabular}{ccccccccccc}
\hline & HDI & OPEN & FDI & BR & DR & MMR & INFAM & SANAT & GDPGR & DEPEND \\
\hline Mean & 0.566 & 97.451 & 1.219 & 20.613 & 6.860 & 269.122 & 37.595 & 60.545 & 7.266 & 59.141 \\
Median & 0.565 & 100.254 & 0.766 & 19.673 & 6.454 & 251.000 & 35.150 & 61.316 & 6.840 & 57.807 \\
Maxi & 0.617 & 116.549 & 6.321 & 27.066 & 8.838 & 423.000 & 57.800 & 69.254 & 18.360 & 77.712 \\
Mini & 0.512 & 75.477 & -0.675 & 17.259 & 6.243 & 183.000 & 24.800 & 49.764 & 2.119 & 46.572 \\
Std. Dev. & 0.036 & 14.274 & 1.612 & 3.114 & 0.807 & 70.143 & 10.626 & 6.447 & 3.485 & 9.861 \\
Skew & 0.046 & -0.178 & 2.181 & 0.695 & 1.241 & 0.704 & 0.498 & -0.293 & 1.602 & 0.424 \\
Kurtosis & 1.397 & 1.600 & 7.139 & 2.204 & 3.276 & 2.389 & 1.937 & 1.752 & 6.366 & 1.959 \\
J-Bera & 2.148 & 1.738 & 30.137 & 2.137 & 5.199 & 1.963 & 1.767 & 1.583 & 18.000 & 1.501 \\
Prob & 0.341 & 0.419 & 0.000 & 0.343 & 0.074 & 0.374 & 0.413 & 0.453 & 0.0001 & 0.471 \\
\hline
\end{tabular}

Source: Authors' estimation

Table 3. Descriptive statistics of Nepal

\begin{tabular}{ccccccccccc}
\hline & HDI & OPEN & FDI & BR & DR & MMR & INFAM & SANAT & GDPGR & DEPEND \\
\hline Mean & 0.516 & 48.355 & 0.249 & 24.024 & 7.055 & 336.492 & 39.959 & 39.289 & 4.376 & 70.516 \\
Median & 0.520 & 46.655 & 0.238 & 22.941 & 6.856 & 314.000 & 38.150 & 39.457 & 4.609 & 71.065 \\
Max & 0.579 & 55.799 & 0.779 & 31.547 & 8.518 & 553.000 & 59.900 & 62.054 & 8.223 & 80.932 \\
Mini & 0.446 & 41.828 & -0.098 & 19.887 & 6.361 & 186.000 & 26.700 & 15.124 & 0.120 & 56.597 \\
Std. Dev. & 0.047 & 4.396 & 0.241 & 3.604 & 0.643 & 117.289 & 10.482 & 15.131 & 1.883 & 7.689 \\
Skew & -0.115 & 0.447 & 0.315 & 0.726 & 0.893 & 0.476 & 0.437 & -0.075 & -0.416 & -0.260 \\
Kurtosis & 1.480 & 1.877 & 2.270 & 2.305 & 2.689 & 1.928 & 1.942 & 1.665 & 3.574 & 1.838 \\
J-Bera & 1.967 & 1.716 & 0.775 & 2.162 & 2.738 & 1.714 & 1.569 & 1.503 & 0.853 \\
Prob & 0.373 & 0.423 & 0.678 & 0.339 & 0.254 & 0.425 & 0.456 & 0.472 & 0.653 \\
\hline
\end{tabular}

Source: Authors' estimation

Table 4. Descriptive statistics of India

\begin{tabular}{ccccccccccc}
\hline & HDI & OPEN & FDI & BR & DR & MMR & INFAM & SANAT & GDPGR & DEPEND \\
\hline Mean & 0.576 & 42.812 & 1.628 & 21.672 & 7.703 & 232.918 & 46.795 & 39.462 & 6.675 & 56.495 \\
Median & 0.576 & 43.204 & 1.592 & 21.435 & 7.547 & 217.500 & 46.200 & 40.192 & 7.461 & 56.434 \\
Max & 0.647 & 55.794 & 3.621 & 26.401 & 8.692 & 370.000 & 66.600 & 59.543 & 8.498 & 64.180 \\
Mini & 0.497 & 25.993 & 0.606 & 17.857 & 7.194 & 145.000 & 29.900 & 16.369 & 3.087 & 49.775 \\
Std. Dev. & 0.049 & 9.110 & 0.721 & 2.923 & 0.514 & 74.279 & 11.739 & 13.882 & 1.683 & 4.686 \\
Skew & -0.107 & -0.411 & 0.887 & 0.182 & 0.575 & 0.453 & 0.157 & -0.162 & -0.906 & 0.106 \\
Kurtosis & 1.719 & 2.289 & 4.065 & 1.585 & 1.906 & 1.844 & 1.732 & 1.700 & 2.414 \\
J-Bera & 1.406 & 0.983 & 3.568 & 1.778 & 2.103 & 1.798 & 1.423 & 1.495 & 3.026 \\
Prob & 0.495 & 0.612 & 0.168 & 0.411 & 0.349 & 0.407 & 0.491 & 0.474 & 0.220 \\
\hline
\end{tabular}

Source: Authors' estimation 
Table 5. Descriptive statistics of Sri-Lanka

\begin{tabular}{ccccccccccc}
\hline & HDI & OPEN & FDI & BR & DR & MMR & INFAM & SANAT & GDPGR & DEPEND \\
\hline Mean & 0.743 & 61.613 & 1.290 & 17.622 & 6.197 & 42.062 & 10.286 & 90.552 & 5.213 & 49.805 \\
Median & 0.747 & 53.952 & 1.199 & 17.949 & 6.169 & 39.500 & 10.150 & 90.682 & 5.226 & 49.012 \\
Max & 0.780 & 88.636 & 1.864 & 18.592 & 6.890 & 56.000 & 15.400 & 95.782 & 9.145 & 53.069 \\
Mini & 0.687 & 46.364 & 0.842 & 15.831 & 5.766 & 36.000 & 6.400 & 84.638 & -1.545 & 47.978 \\
Std. Dev. & 0.030 & 13.649 & 0.319 & 0.967 & 0.323 & 6.538 & 2.752 & 3.592 & 2.374 & 1.815 \\
Skew & -0.453 & 0.517 & 0.557 & -0.522 & 0.400 & 0.709 & 0.221 & -0.134 & -0.808 & 0.627 \\
Kurtosis & 1.878 & 1.748 & 2.210 & 1.751 & 2.188 & 2.173 & 1.879 & 1.681 & 4.512 & 1.784 \\
J-Bera & 1.730 & 2.197 & 1.554 & 2.209 & 1.083 & 2.243 & 1.209 & 1.509 & 4.081 & 2.544 \\
Prob & 0.421 & 0.333 & 0.459 & 0.331 & 0.582 & 0.326 & 0.546 & 0.470 & 0.129 & 0.280 \\
\hline
\end{tabular}

Source: Authors' estimation

Table 6. Descriptive statistics of Pakistan

\begin{tabular}{ccccccccccc}
\hline & HDI & OPEN & FDI & BR & DR & MMR & INFAM & SANAT & GDPGR & DEPEND \\
\hline Mean & 0.516 & 31.082 & 1.242 & 30.712 & 7.715 & 200.498 & 71.663 & 47.278 & 4.436 & 73.907 \\
Median & 0.522 & 31.486 & 0.853 & 30.210 & 7.627 & 195.000 & 71.250 & 48.266 & 4.703 & 72.869 \\
Max & 0.560 & 35.682 & 3.668 & 34.703 & 8.862 & 286.000 & 87.800 & 59.869 & 7.667 & 85.048 \\
Mini & 0.449 & 25.306 & 0.383 & 28.250 & 6.942 & 140.000 & 57.200 & 31.366 & 1.607 & 65.515 \\
Std. Dev. & 0.035 & 3.096 & 0.979 & 1.889 & 0.614 & 46.745 & 9.669 & 9.0541 & 1.731 & 6.517 \\
Skew & -0.499 & -0.283 & 1.486 & 0.679 & 0.384 & 0.373 & 0.120 & -0.278 & 0.009 & 0.311 \\
Kurtosis & 2.069 & 2.109 & 3.859 & 2.363 & 1.862 & 1.847 & 1.7432 & 1.781 & 2.306 & 1.723 \\
J-Bera & 1.555 & 0.926 & 7.978 & 1.874 & 1.570 & 1.569 & 1.364 & 1.496 & 0.401 & 1.680 \\
Prob & 0.459 & 0.629 & 0.019 & 0.392 & 0.456 & 0.456 & 0.506 & 0.473 & 0.818 & 0.432 \\
\hline
\end{tabular}

Source: Authors' estimation

Figure 1(a) is representing a negative relationship between HDI and birth rate. It is confirmed in Figure 1(b) that HDI and maternal mortality rate possess a negative relation. Figure 1(c) is showing no significant connection between HDI and GDP growth. However, a positive relationship has been seen in Figure 1(d), between HDI and sanitation facilities access. Both infant mortality rate and dependency ratio shows a significant negative relation in Figure 1(e) and Figure 1(f), respectively.

The correlation matrix in Table 7 shows that trade openness is positively linked with HDI. Also, its relation is positive with FDI. The correlation matrix suggests a negative connection of HDI with birth and death rate, but the relationship it shows between sanitation facility and GDP growth is positive. While presenting a negative relation between human development and infant mortality rate. The correlation matrix also indicates that the dependency and maternal mortality rates are negatively correlated with HDI. 


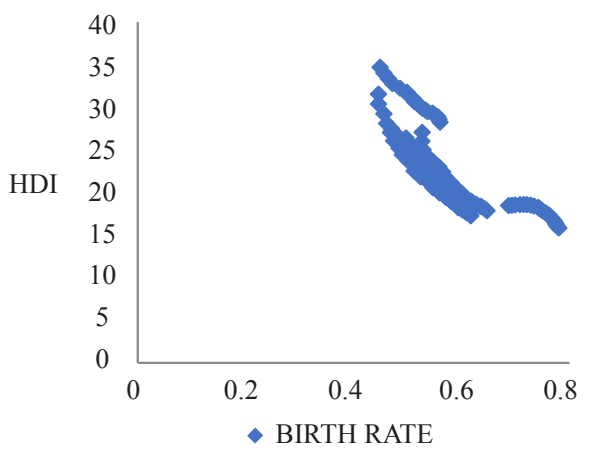

(a)

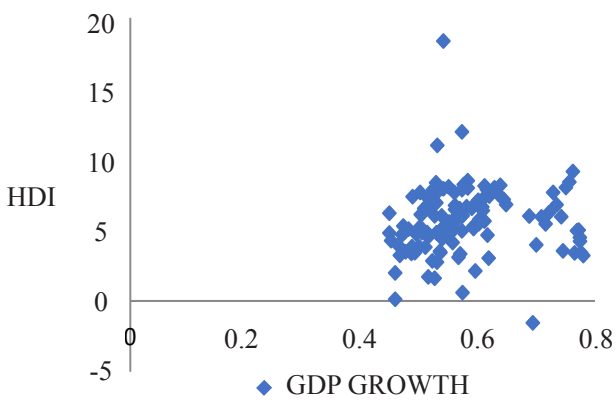

(c)

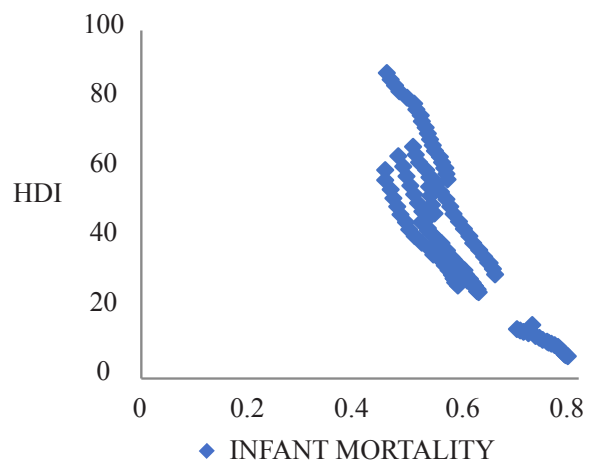

(e)

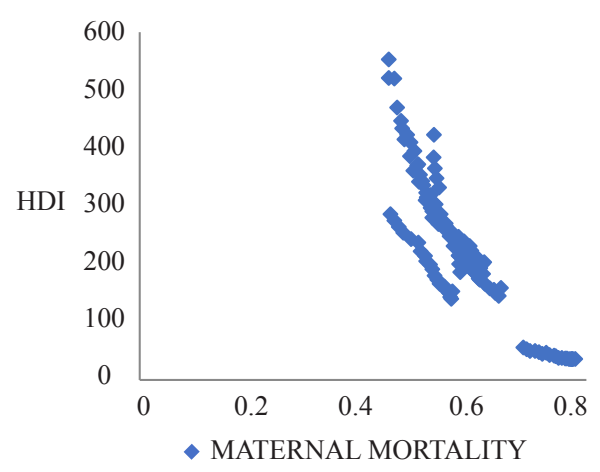

(b)

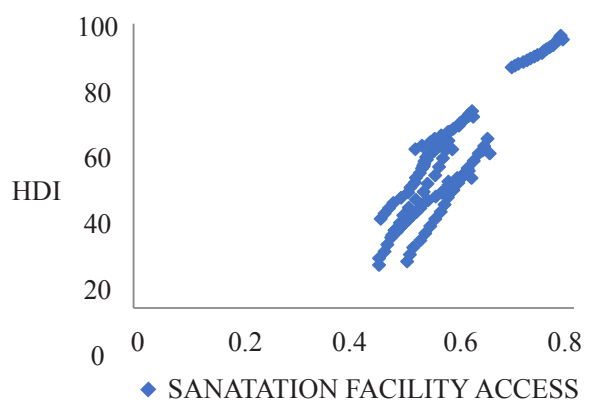

(d)

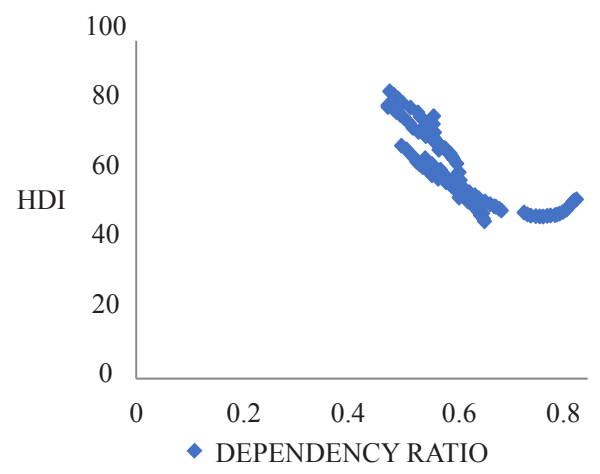

(f)

Source: Authors' estimation

Figure1. Scatter plot of HDI and explanatory variables

Table 7. Correlation Matrix

\begin{tabular}{|c|c|c|c|c|c|c|c|c|c|c|}
\hline & HDI & FDI & SANAT & GDPGR & MMR & $\mathrm{BR}$ & $\mathrm{DR}$ & INFAM & DEPEND & OPEN \\
\hline HDI & 1 & & & & & & & & & \\
\hline FDI & 0.199 & 1 & & & & & & & & \\
\hline SANAT & 0.911 & 0.167 & 1 & & & & & & & \\
\hline GDPGR & 0.074 & 0.461 & 0.043 & 1 & & & & & & \\
\hline MMR & -0.873 & -0.283 & -0.865 & -0.013 & 1 & & & & & \\
\hline $\mathrm{BR}$ & -0.776 & -0.132 & -0.640 & -0.226 & 0.546 & 1 & & & & \\
\hline DR & -0.546 & 0.002 & -0.518 & -0.094 & 0.472 & 0.718 & 1 & & & \\
\hline INFANM & -0.854 & -0.031 & -0.759 & -0.107 & 0.605 & 0.935 & 0.746 & 1 & & \\
\hline DEPEND & -0.806 & -0.206 & -0.649 & -0.222 & 0.684 & 0.909 & 0.701 & 0.824 & 1 & \\
\hline OPEN & 0.252 & 0.182 & 0.429 & 0.283 & -0.096 & -0.478 & -0.245 & -0.434 & -0.352 & 1 \\
\hline
\end{tabular}

Source: Authors' estimation 


\subsection{Model estimation results}

As this study uses panel data for estimation, therefore our first concern is to determine whether the fixed-effect or random-effect model is appropriate. For the selection of a fixed-effect model or random-effect model, the Hausman test has been employed. Hausman test detects endogenous regressor or predictor variable in regression model. The null hypothesis of Hausman test is that the preferred model is random effect. While the alternative hypothesis is that the fixed effect model is appropriate. Results in Table 8, indicate that the fixed effect model is appropriate for this study, as the null hypothesis has been rejected. Therefore, we employed a fixed-effect model for our estimation.

Table 8. Hausman test result for model selection

\begin{tabular}{cccc}
\hline Test Summary & Chi-square statistic & Degree of freedom & Probability \\
\hline Period Random & 21.757 & 9 & 0.0097 \\
\hline Source: Authors' Estimation & &
\end{tabular}

Table 9 shows the results of Fixed effect model. Similar to the study of Yanikkaya (2002), the estimation result shows that for countries (Pakistan, India, Sri-Lanka, Bhutan, Bangladesh, and Nepal), GDP growth has a significant positive impact on HDI. However, the coefficient is small, that is, every one percent increase in GDP growth will raise the HDI level up to 0.002 only. The impact of trade openness supported to be positive by many works of literature like Waheed and Tehseen (2017), Olagunju (2019), Figueroa (2014) but in our case the impact is negative, which proved the statement of Salvatore and Wiley (2004) and Dash et al. (2018). The result of trade openness and HDI relation exhibit that every $1 \%$ increase in trade openness will decrease HDI by 0.045 .

Table 9. Estimation results of fixed effect model

\begin{tabular}{ccccc}
\hline Variable & Coefficient & Standard Error & t-Statistic & Probability \\
\hline Constant & 0.688 & 0.088 & 7.792 & 0.000 \\
OPEN & -0.045 & 0.009 & -4.593 & 0.000 \\
FDI & 0.003 & 0.002 & 1.433 & 0.155 \\
BR & 0.016 & 0.063 & 0.254 & 0.799 \\
DR & 0.234 & 0.028 & 8.224 & 0.000 \\
GDPGR & 0.002 & 0.001 & 2.179 & 0.032 \\
MMR & -0.024 & 0.019 & -1.274 & 0.206 \\
DEPEND & -0.355 & 0.055 & -6.456 & 0.000 \\
INFAM & -0.107 & 0.021 & -5.037 & 0.000 \\
SANAT & 0.096 & 0.016 & 5.894 & 0.000 \\
Adj.R ${ }^{2}$ & 0.988 & & F-statistic & \\
DW Statistic & 0.579 & Probability (F-stat.) & 366.297 \\
\hline
\end{tabular}

Source: Authors' Estimation

Although Foreign direct investment shows a positive influence which supports the study of Sharma and Gani (2004), however, it is not statistically significant. Dependent population ratio has a highly significant negative impact on HDI. Higher ratio of dependent population means less labor force participation, in countries like Pakistan, India, Bangladesh, Bhutan, women's life is limited to house hold work and the societal norms restrict women to participate in labor force. The low HDI of selected South Asian countries is a result of such societal norms, as no country will progress well if almost half of its population does not participate in labor force. The coefficient of DEPEND indicates that every $1 \%$ 
increase in the ratio of dependent population will decrease the Human Development Index level by 0.36 .

It has been observed that maternal mortality ratio and infant mortality ratio has a negative relation with HDI, which is an obvious and expected result as the countries that thrive for the development of its citizens would give priority to health sector. However, the result of birth rate, and death rate indicates that both variables have positive impact on HDI. Although, the birth rate is statistically insignificant. While in developing economies, the increased death rate reduces the economic burden, and hence it has significant, positive impact, that is, every $1 \%$ increase in death rate increases the Human Development Index level by 0.23 .

Increased access to sanitation facilities has a highly significant positive impact on human development. Every $1 \%$ increase in the population access to necessary sanitation facilities would boost the level of HDI by 0.96 . The result confirms the study of Eufuszari (1996).

The goodness of fit stood at $98.8 \%$, which confirms that the model is a good fit model. Although Durban Watson indicates the presence of autocorrelation, however for the panel data study with a period of fewer than 30 years, it is not worth concerning. The probability of F-statistic shows that the model is overall statistically significant.

\section{Conclusion and policy implications}

Based on estimation results, it can be concluded that the impact of trade openness on human development is harmful to developing countries as it has been expected and supported by many earlier literatures like (Dowrick \& Golley, 2004; Figueroa, 2014; Sabi, 2007; Salvatore \& Wiley, 2004). This negative impact of globalization is mainly due to the internal features of the country. It has also been observed that the countries facing negative trade openness and HDI relations have a high dependent population ratio, high infant and maternal mortality rates, and lack of basic facilities like sanitation services. The result confirms the study of Eufuszari (1996). Although the impact of foreign direct investment is positive, it is insignificant because in developing the private and public investment is low. Therefore, growth depends on FDI, but the host country could not get all its benefits as the investment made by external sources repatriate the profit to their own country.

An increase in birth rate is positively linked with HDI, as the cause of increased birth rate is associated with improved health facilities in the country. However, it is insignificant because it increases the dependent population ratio in the country. As population density is usually high in developing countries, the population increase results in an excess burden on the economy. Therefore, in developing economies, the increased death rate reduces the economic burden and thus sheds a positive impact on the overall human development index.

It has been suggested that developing countries should initiate to produce finished goods and should strive to increase their export and decrease imports. The government should strive to reduce maternal mortality and infant mortality, provide access to sanitation facility, and encourage the female labor force's participation. Institutions should be developed to provide technical skills to the public for greater labor force participation.

This research can be further proceeded by considering more countries in the sample. A comparative analysis of developed countries and developing countries can also be made to analyze globalization's diverse impact.

\section{Reference}

Chang, R., Kaltani, L., \& Loayza, N. V. (2009). Openness can be good for growth: The role of policy complementarities. Journal of Development Economics, 90, 33-49.

Dash, S., Rath, S., \& Pati, U. (2018). Financial globalization and its impact on human development: A comparative analysis of India, Singapore, and Japan. Revista Espacios, 39(14), 20-38.

Dowrick, S., \& Golley, J. (2004). Trade openness and growth, who benefits? Oxford Review of Economic Policies, $20(1), 38-56$.

Eusufzai, Z. (1996). Openness, economic growth, and development. Some further results, Economic Development and Cultural Change, 44(2), 333-338.

Figueroa, A. M. (2014). The impact of globalization on human development in the developing countries: The case of central and South America. Revista Eletrônica de Ciência Política, 5(2), 24-41. 
Frankel, J. A., \& Romer, D. (1999). Does trade cause growth? American Economic Review, 89, 379-399.

Freund, C., \& Bolaky, B. (2008). Trade, regulations, and income. Journal of Development Economics, 87, $309-321$.

Jawaid, T., \& Waheed, A. (2017). Contribution of international trade in human development of Pakistan. Global Business Review, 18(5), 1155-1177.

Keho, Y. (2017). The impact of trade openness on economic growth: The case of Cote d'Ivoire. Journal Cogent Economics \& Finance, 5(1), 1-15.

Khandare, V. B., \& Babar, S. N. (2012). Trade among SAARC countries: With special reference to India. IJIBF, 2(1), 127-137.

Musila, J. W., \& Yiheyis, Z. (2015). The impact of trade openness on growth: The case of Kenya. Journal of Policy Modeling, 37, 342-354.

Olagunju, K., Ogunniyi, A., Oguntegbe, K. F, \& Oluwole, I. (2019). Welfare impact of globalization in developing countries: Examining the mediating role of human capital. Economies, 7, 84-108.

Polat, A., Shahbaz, M., Rehman, I. U., \& Satti, S. L. (2015). Revisiting linkages between financial development, trade openness and economic growth in South Africa: Fresh evidence from combined cointegration test. Quality and Quantity, 49, 785-803.

Sabi, M. (2007). Globalization and human development. International Conference on Globalization and Its Discontents, Cortland (pp. 102-119).

Salvatore, D., \& Wiley, J. (2004). An Introduction to International Economics (3rd ed.). John Wiley \& Sons.

Sapkota, J. B. (2011). Globalization and human aspect of development in developing countries: Evidence from panel data. Journal of Globalization Studies, 2(1), 78-96.

Sharma, B., \& Gani, A. (2004). The effects of foreign direct investment on human development. Global Economy Journal, 4(2): 1-18.

Ulasan, B. (2015). Trade openness and economic growth: Panel evidence. Applied Economics Letters, 22, $163-167$.

Yanikkaya, H. (2002). Trade openness and economic growth: A cross-country empirical investigation. Elsevier Science B.V., 72(1): 57-89. 